\title{
Association between estrogen levels and temporomandibular disorders: a systematic literature review
}

\author{
Marcin Berger ${ }^{1}$, Leszek Szalewski², Magdalena Bakalczuk ${ }^{1}$, Grzegorz Bakalczuk³ ${ }^{3}$ Szymon Bakalczuk ${ }^{4}$, \\ Jacek Szkutnik ${ }^{1}$
}

${ }^{1}$ Department of Functional Masticatory Disorders, Medical University of Lublin, Lublin, Poland

2Department of Prosthetic Dentistry, Medical University of Lublin, Lublin, Poland

${ }^{3}$ Department of Obstetrics, Gynaecology and Obstetrical-Gynaecological Nursing, Medical University of Lublin, Lublin, Poland

${ }^{4}$ Non-Public Health Care Unit ‘Ovum Reproduction and Andrology', Lublin, Poland

\begin{abstract}
Introduction: To evaluate whether the hypothesis that estrogen levels are associated with temporomandibular disorders (TMD) in humans can be confirmed or contradicted by available literature.

Material and methods: A systematic review based on the content of PubMed, Scopus, and Cochrane Library databases was performed. Studies were identified using a combination of key words 'temporomandibular disorder' and 'estrogen'. Nine studies were included into our review.

Results: The relationship between estrogen levels and TMD was found in seven out of nine reviewed papers. Results from two papers suggest that a high estrogen level is associated with an increased prevalence of TMD. Five additional papers found a relationship between a low estrogen level and an increase in TMD pain. In considering the value of evidence and inconsistencies of results in the reviewed publications, we state that there is weak evidence to support the hypothesis that estrogen levels are associated with TMD.

Conclusions: Results of reviewed studies were divergent and sometimes contradictory. One possible explanation is that estrogen influences TMD pain processing differently than temporomandibular joints (TMJ) structures, as shown in many animal studies. Estrogen may influence TMD pain processing differently than TMJ structures. We suggest consideration of the dual action of estrogen when planning future studies on its association with TMD.
\end{abstract}

Key words: temporomandibular disorders, estrogen level, menopause, hormone replacement therapy.

\section{Introduction}

The term 'temporomandibular disorder' (TMD) embraces a number of clinical problems that involve the masticatory muscles and/or temporomandibular joints (TMJ) and associated structures. Temporomandibular disorder is the second most prevalent source of orofacial pain [1]. A number of studies have also identified genetic (e.g., COMT, SCN1A) and inflammatory criteria of (e.g., free radicals and cytokines) risk factors that contribute to the development of TMD [2-4]. According to epidemiological data, there is a strong predilection of TMD for women [5]. The prevalence is the highest during reproductive years and the lowest before puberty and after menopause. The male to female ratio of TMD patients is estimated at around $1: 3$ [6]. It is suspected that this predisposition is related to female reproductive hormones, especially estrogen. The effects of estrogen are mediated by binding to its receptors. Three types of estrogen receptors are distinguished, two nuclear - alpha
$(E R \alpha)$ and beta (ER $\beta)$, and one plasmatic - G-protein coupled estrogen receptor 1 (GPER1) [7]. Since 1986, when estrogen receptors were recognized for the first time in baboon temporomandibular joints, the potential influence of estrogen on TMD has become a matter of interest to many researchers. It is now known that estrogen receptors are localized in many structures of the stomatognathic organ, particularly TMJ tissues, such as chondroid tissue of condyle and retrodiscal tissues [8]. Studies on the effect of estrogen deficiency performed on animal models revealed that estrogen depletion causes structural changes in TMJ. These include an increase in TMJ cartilage thickness, a decrease in subchondral bone volume, flattening of condyles, osteophyte formation or even serial degenerative changes [9-14].

The effect of estrogen on the development, restitution and metabolism of the temporomandibular joint and associated structures is one of the possible mechanisms in which these hormones can influence 
the incidence of TMD. Another probable mechanism is the modulation of the pain regulative mechanisms by estrogen [15]. The presence of its receptors in tissues of both the peripheral and central nervous systems makes estrogen capable of modifying pain signaling $[16,17]$. Estrogen receptors $(E R \alpha, E R \beta)$ are found in the dorsal root ganglion (DRG) as well as in the trigeminal nerve nucleus. The influence of estrogen on pain regulatory mechanisms seems to be very complex. Depending on the pain signaling type, estrogen may act as a pro- and anti-nociceptive. In physiological pain, estrogen seems to decrease pain while, in inflammatory pain, estrogen acts differently depending on the inflammation type. In acute inflammatory pain caused by formalin or ATP injection, estrogen has an anti-nociceptive effect. In the chronic inflammatory pain model with complete Freund's adjuvant (CFA) or carrageen injection, the pronociceptive effect of this hormone is seen [18-21]. It is worth noting that blocking estrogen receptors $\alpha$ and $\beta$ diminishes sex differences in both physiologic and acute inflammatory pain [22]. Recently, some estrogen related genetic factors predisposing to TMD have been discovered. ER $\alpha$ gene polymorphism causes receptor overexpression which makes certain allele carriers more susceptible to the effects of estrogen by enhancing processes associated with ER $\alpha$ receptor stimulation [23].

The aim of our study is to determine whether the hypothesis that estrogen levels are associated with temporomandibular disorders in humans can be confirmed or contradicted by available literature.

\section{Material and methods}

Material for our study consisted of publications identified by searches performed independently by two authors using the Medline/PubMed database, the Cochrane Collaboration database, and the Scopus database. Search strategy is illustrated on the flowchart (Fig. 1). In order to identify relevant publications, a search using a combination of key words "estrogens" and "temporomandibular joint disorders" (according to Medical Subject Headings - MeSH) was performed.

For the first step of screening, one reviewer read the titles of all 96 papers retrieved from the searches and removed all duplicates and papers unavailable in full text, leaving 72 records. The second step of screening involved abstract reviewing. Full-text articles were obtained for all abstracts except for case reports, reviews, studies on animals, articles which were not addressed to estrogen levels or to our review question and those unavailable in English (Table I). After a manual search of references of identified studies, two more papers were included in our analysis. If after analyzing the full text, the eligibility of an article was still uncertain, the second reviewer undertook a full-text analysis of the article to determine its eligibility. There were no events of disagreement between the reviewers. After evaluation, nine studies were included in our review. All studies were based on the same subject - the influence of estrogen on TMD. How they were focused on different aspects of this issue will be discussed in detail. Aims, methods and material of the studies, as well as results and conclusions, are described in the data extraction tables (Table II-IV). The questions for scoring are based on the "Cochrane Handbook for Systematic Reviews of Interventions 4.2.6 Updated September 2006", PRISMA 2009 Checklist, "Advice on how to write a systematic review. JM Wardlaw. 14 ${ }^{\text {th }}$ January 2010" and the quality assessment tool for diagnostic accuracy studies (QUADAS) recommended by the Cochrane Collaboration. Studies were scored according to questions shown in Table V. Each article was scored from 0 to 2 and the scores were tallied up. The methodology of each selected article was evaluated and information placed in Table VI. Scores 0-8 were rated as the poor value of evidence, whereas scores 9-11 and 12-14 were rated as a moderate and high value of evidence.

\section{Results}

Evaluated papers had many limitations, particularly the small sample size and lack of estrogen level assessment. Additionally, some papers did not contain correct exclusion criteria which could have influenced the outcome. Temporomandibular disorders diagnoses in most of the studies were based on clinical examination according to RDC (research diagnostic criteria)/TMD criteria. Papers not based on the RDC/TMD protocol were deemed unsatisfactory for our purposes since they limited the possibility for comparison between studies. Finally, as noted in Table VI, studies varied in the value of

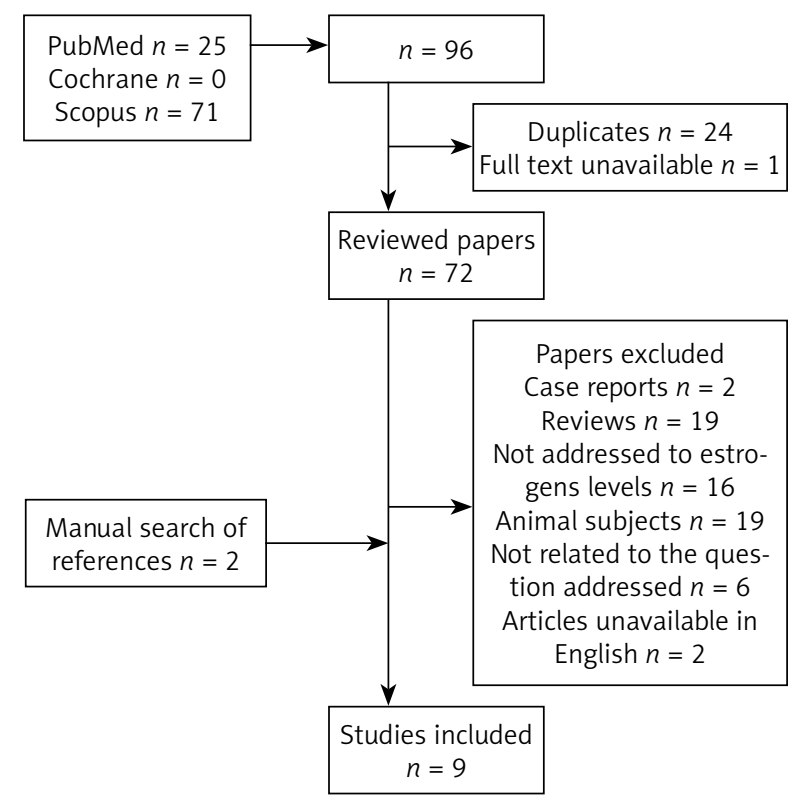

Fig. 1. Search strategy flow chart 
Tab. I. Excluded studies and the main reasons for exclusion

\begin{tabular}{ll}
\hline Reason for exclusion & First author \\
\hline Case reports & Wolford and Cardenas, 1999; Miles et al., 2006 \\
\hline Reviews & Green, 1999; Gremillion, 2000; Hatch et al., 2001; Woda and Pionchon, 2001; Levin, 2002; \\
& Nozawa-Inoue et al., 2003; Milam, 2003; Nekora-Azak, 2004; Kuba and Quinones-Jenab, 2005; \\
& Dervis, 2005; Hukins, 2006; Craft, 2007; Lund and Lundeberg, 2008; Galal et al., 2008; Martin, 2009; \\
& Bereiter and Okamoto, 2011; De Tommaso, 2011; Meloto et al., 2011; Sasa et al., 2012 \\
\hline Estrogens levels not & Abubaker et al., 1993; Campbell et al., 1993; Abeyama et al., 1997; Warren and Fried, 2001; Kapila, 2003; \\
assessed & Lee et al., 2006; Kang et al., 2007; Henry et al., 2008; Wang et al., 2008; Mulak et al., 2008; Ribeiro-Dasilva \\
& et al., 2009; Yu et al., 2009; Kim et al., 2010; Wu et al., 2012; Schopper and Irnich, 2013; Weiler et al., 2013 \\
\hline Animal subjects & Aufdemorte et al., 1986; Okuda et al., 1996; Abubaker, 2000; Yasuoka et al., 2000; Cairns et al., 2002; \\
& Yamada et al., 2003; Flake et al., 2005; Guan et al., 2005; Flake et al., 2006; Bereiter et al., 2006, 2006; \\
& Min et al., 2007; Kishimoto et al., 2007; Fischer et al., 2007; Yun et al., 2008; Fischer et al., 2008; \\
& Tashiro et al., 2008, 2009; Puri et al., 2009 \\
\hline Not related to the & $\begin{array}{l}\text { Fillingim, 2002; Gruber and Gregg, 2003; Milam, 2003; LeResche, 2004; Herrera et al., 2007; Das and } \\
\text { question addressed }\end{array}$ \\
\hline Rajalingham, 2012 \\
\hline
\end{tabular}

evidence. Two papers showed a high value of evidence $[24,25]$, three papers showed a moderate value of evidence [26-28]; and four papers demonstrated a poor value of evidence [5, 29-31].

The relationship between estrogen levels and TMD was noted in seven out of nine evaluated papers. The results of Nekora Azak et al. and Hatch et al. studies $[29,31]$, evaluating the relationship between hormone replacement therapy and prevalence of TMD signs and symptoms, did not reveal this relationship. Results from two reports $[27,28]$ suggest that the high estrogen level is associated with an increased prevalence of TMD. In addition, in one paper [32], it was observed that the use of exogenous estrogen also increases a risk of TMD. According to the studies by Landi et al., pathology of TMJ (group II and/or III RDC/TMD) is associated with high levels of estrogen in both males and females (luteal phase only) $[27,28]$. Three papers [25, 27, 28] found a relationship between a low estrogen level and the increase in TMD pain, which seems to be in contrast with the results of other studies [30-32].

In considering the value of evidence and inconsistencies of results in the reviewed publications, we state that there is weak evidence to support the hypothesis that estrogen levels are associated with TMD.

\section{Discussion}

In the reviewed studies, only two did not reveal an association between estrogen levels and $\operatorname{TMD}[29,31]$. Both studies analyzed the effect of exogenous estrogens use on TMD and in our review obtained a poor value from scoring. These results stand in contrast to results of LeResche et al., where the use of exogenous estrogens was also analyzed [32]. Results of NekoraAzak et al. study can be affected by the fact that time between menopause and introduction of hormone ther- apy was not considered in allocation to study groups [31]. It seems important because as animal studies show after estrogen depletion by ovariectomy, some TMJ structures can be affected by the lack of estrogen. In patients whose time after menopause was longer, structural abnormalities of TMJ could have developed. Therefore, it would be improper to place them in the same study group with patients with a shorter period between menopause and hormonal therapy. This could be one of the reasons why there were no significant differences between postmenopausal women using and those not using hormone replacement therapy.

Other reviewed papers showed that there is a relationship between estrogen and TMD, but their results are contradictory. Studies by Dao, LeResche, and Sherman showed that a high estrogen level reduced TMD pain [24-26, 30, 32]. The studies by Landi [27, 28] showed that painful TMD, namely RDC/TMD Axis I group II and/or III diagnosis, are associated with high estrogen levels. Based on the study by LeResche it is not possible to determine which subgroups of painful TMD are affected by estrogen due to the lack of sufficient data [32]. Therefore, we can only speculate that estrogen influences TMD pain processing differently than TMJ structures. It is worth noting that in this study it is thought that the increased prevalence of TMD in the studied group may be due to the fact that the study was conducted when hormone replacement therapy, in particular, estrogen replacement therapy, was administered primarily to women who had undergone a hysterectomy [33]. The surgery itself could also have an effect on the temporomandibular joint because endotracheal intubation can cause transient TMD pain [34]. That is why post-surgery patients should have been excluded from the study.

In the studies by Landi et al., where the association of estrogen levels and degenerative joint disease 
Tab. II. Data extraction: aims and methods of the studies

\begin{tabular}{|c|c|c|}
\hline Authors & Title and year of publication & Aim and method of the study \\
\hline LeResche et al. & $\begin{array}{l}\text { Use of exogenous hormones } \\
\text { and the risk of temporoman- } \\
\text { dibular disorder pain } \\
1997\end{array}$ & $\begin{array}{l}\text { Aim of the study: } \\
\text { "Two studies are reported here. The first study was designed to examine } \\
\text { the possible relationships of exogenous hormone use and risk of TMD } \\
\text { among post-menopausal women. In the second study, we employed a simi- } \\
\text { lar approach to examine whether oral contraceptive use is associated with } \\
\text { an increased risk of TMD in younger women." } \\
\text { Compared variables: } \\
\text { Information about referral for TMD treatment } \\
\text { Information about hormone replacement therapy } \\
\text { Information about use of oral contraceptives } \\
\text { TMD diagnosis method: } \\
\text { Information about referral for TMD treatment in healthcare company's } \\
\text { database } \\
\text { Estrogen level assessment: } \\
\text { None }\end{array}$ \\
\hline Dao et al. & $\begin{array}{l}\text { Modulation of myofascial pain } \\
\text { by the reproductive hormones: } \\
\text { A preliminary report } \\
1998\end{array}$ & $\begin{array}{l}\text { Aim of the study: } \\
\text { "The potential influence of these hormones on myofascial pain was evalu- } \\
\text { ated." } \\
\text { Compared variables: } \\
\text { Daily pain level on VAS } \\
\text { Use of oral contraceptives } \\
\text { TMD diagnosis method: } \\
\text { Criteria according to RDC/TMD } \\
\text { Estrogen level assessment: } \\
\text { None }\end{array}$ \\
\hline Hatch et al. & $\begin{array}{l}\text { Is use of exogenous estrogen } \\
\text { associated with temporoman- } \\
\text { dibular signs and symptoms? } \\
2001\end{array}$ & $\begin{array}{l}\text { Aim of the study: } \\
\text { To determine the association between exogenous estrogen use and signs } \\
\text { and symptoms of TMD by direct physical examination in a randomly } \\
\text { selected community sample of primarily postmenopausal women. } \\
\text { Compared variables: } \\
\text { Signs and symptoms of TMD } \\
\text { Use of exogenous estrogens } \\
\text { TMD diagnosis method: } \\
\text { Craniomandibular Index (CMI) } \\
\text { Estrogen level assessment: } \\
\text { None }\end{array}$ \\
\hline LeResche et al. & $\begin{array}{l}\text { Changes in temporomandibu- } \\
\text { lar pain and other symptoms } \\
\text { across the menstrual cycle } \\
2003\end{array}$ & $\begin{array}{l}\text { Aim of the study: } \\
\text { "The objective of this study was to assess changes in levels of clinical tem- } \\
\text { poromandibular (TMD) pain in relation to phases of the menstrual cycle." } \\
\text { Compared variables: } \\
\text { Daily pain level on VAS } \\
\text { Use of oral contraceptives } \\
\text { Sex } \\
\text { TMD diagnosis method: } \\
\text { Clinical examination according to RDC/TMD } \\
\text { Estrogen level assessment: } \\
\text { None }\end{array}$ \\
\hline Landi et al. & $\begin{array}{l}17-\beta \text {-estradiol and progester- } \\
\text { one serum levels in temporo- } \\
\text { mandibular disorder patients } \\
2004\end{array}$ & $\begin{array}{l}\text { Aim of the study: } \\
\text { "To evaluate estrogen (17-beta-estradiol) and progesterone serum levels in } \\
\text { a young adult population affected by articular forms of temporomandibular } \\
\text { disorders (TMD) versus a control group of healthy subjects." } \\
\text { Compared variables: } \\
\text { Estrogen levels } \\
\text { Axis I group II and/or III diagnosis according to RDC/TMD criteria } \\
\text { TMD diagnosis method: } \\
\text { Clinical examination according to RDC/TMD } \\
\text { Estrogen level assessment: } \\
\text { Blood samples }\end{array}$ \\
\hline
\end{tabular}


Tab. II. Cont.

\begin{tabular}{|c|c|c|}
\hline Authors & Title and year of publication & Aim and method of the study \\
\hline LeResche et al. & $\begin{array}{l}\text { Musculoskeletal orofacial pain } \\
\text { and other signs and symp- } \\
\text { toms of temporomandibular } \\
\text { disorders during pregnancy: } \\
\text { a prospective study } \\
2005\end{array}$ & $\begin{array}{l}\text { Aim of the study: } \\
\text { "To describe the course of reported musculoskeletal pain in the temporo- } \\
\text { mandibular region and other signs and symptoms of temporomandibular } \\
\text { disorders (TMD) as well as psychological distress over the course of preg- } \\
\text { nancy and one year postpartum." } \\
\text { Compared variables: } \\
\text { Musculoskeletal pain in the temporomandibular region } \\
\text { Estrogen levels (measured in the } 3^{\text {rd }}, 6^{\text {th }} \text { and } 9^{\text {th }} \text { month of pregnancy and } \\
\text { one year postpartum) } \\
\text { Pain severity (the Graded Chronic Pain Scale) } \\
\text { TMD diagnosis method: } \\
\text { Clinical examination according to RDC/TMD } \\
\text { Estrogen level assessment: } \\
\text { Unstimulated saliva samples }\end{array}$ \\
\hline Landi et al. & $\begin{array}{l}\text { Sexual hormone serum levels } \\
\text { and temporomandibular } \\
\text { disorders. } \\
\text { A preliminary study } \\
2005\end{array}$ & $\begin{array}{l}\text { Aim of the study: } \\
\text { "The aim of the present study was to investigate the role of sexual hor- } \\
\text { mones in a young adult population affected by articular forms of tempo- } \\
\text { romandibular disorders (TMD), measuring 17b-estradiol and progesterone } \\
\text { serum levels." } \\
\text { Compared variables: } \\
\text { Estrogen levels } \\
\text { Axis I group II and/or III diagnosis according to RDC/TMD criteria } \\
\text { TMD diagnosis method: } \\
\text { Clinical examination according to RDC/TMD } \\
\text { Estrogen level assessment: } \\
\text { Blood samples } \\
\text { Males: } 1 \text { sample taken once } \\
\text { Females: } 2 \text { samples ( } 5-7 \text { day of the cycle [luteal phase] and } 22-25 \text { day } \\
\text { of the same cycle [follicular phase]) }\end{array}$ \\
\hline Sherman et al. & $\begin{array}{l}\text { Cyclic effects on experimental } \\
\text { pain response in women with } \\
\text { temporomandibular disorders } \\
2005\end{array}$ & $\begin{array}{l}\text { Aim of the study: } \\
\text { To assess variations in experimental pain response at } 4 \text { phases of the } \\
\text { menstrual cycle. } \\
\text { Compared variables: } \\
\text { Use of oral contraceptives } \\
\text { RDC/TMD diagnosis } \\
\text { TMD diagnosis method: } \\
\text { Clinical examination according to RDC/TMD } \\
\text { Estrogen level assessment: } \\
\text { None }\end{array}$ \\
\hline $\begin{array}{l}\text { Nekora-Azak } \\
\text { et al. }\end{array}$ & $\begin{array}{l}\text { Estrogen replacement therapy } \\
\text { among postmenopausal wom- } \\
\text { en and its effects on signs and } \\
\text { symptoms of temporomandibu- } \\
\text { lar disorders } \\
2008\end{array}$ & $\begin{array}{l}\text { Aim of the study: } \\
\text { "The aim of this study was to investigate the relationship between post- } \\
\text { menopausal hormone use and TMD in Turkish postmenopausal women." } \\
\text { Compared variables: } \\
\text { Signs and symptoms of TMD } \\
\text { Hormone replacement therapy } \\
\text { TMD diagnosis method: } \\
\text { Questionnaire and clinical examination } \\
\text { Estrogen level assessment: } \\
\text { None }\end{array}$ \\
\hline
\end{tabular}

(group II and/or III RDC/TMD) was evaluated, the authors stated that a high estrogen level is associated with an increased prevalence of TMD, which finding can be confirmed by results of studies on animal models $[27,28]$. Estrogen can be implied in the development of the degenerative joint disease because of its effect on matrix composition in TMJ fibrocartilage [35]. In studies where the influence of estrogen deficiency on TMJ was evaluated, it was found that lack of estrogen can also induce pathological changes in TMJ. Estrogen reduces sulfated proteoglycan synthesis of articular cartilage in an animal model [36]. It can also influence the synovial membrane through its effect on the collagen and protein content of the TMJ disc [37]. Collagen and elastin make up a great deal of the temporomandibular joint disc's structure and are often found to be altered in the presence of TMD symptoms. The direct influence of sex hormones on changes in collagen and elastin synthesis is well established [38]. After ovariectomy, an increase in the soft tissue layer and a decrease in bone volume and density in the TMJ is observed [39]. Replacement with estrogen can restore most of the changed histomorphometric parameters of TMJ [14]. It is also interesting that $E R \alpha$ receptor polymorphism is associated 
Tab. III. Data extraction: material of the studies

\begin{tabular}{|c|c|c|}
\hline Authors & Title and year of publication & Material \\
\hline LeResche et al. & $\begin{array}{l}\text { Use of exogenous hormones } \\
\text { and the risk of temporoman- } \\
\text { dibular disorder pain } \\
1997\end{array}$ & $\begin{array}{l}\text { Location: USA } \\
\text { Age: Study I: }>40 \text { years; Study II: } 15-35 \text { years } \\
\text { Sex: Females } \\
\text { Sample size: } 13820 \\
\text { Study groups: } \\
\text { Study I: } 1291 \text { females referred for TMD treatment } \\
\text { Study II: } 1473 \text { females referred for TMD treatment } \\
\text { Control groups: } \\
\text { Study I: } 5164 \text { females without TMD } \\
\text { Study II: } 5892 \text { females without TMD } \\
\text { Inclusion criteria: Based on information from healthcare company's database: } \\
\text { Study I: women > } 40 \text { years old referred for TMD treatment } \\
\text { Study II: women aged } 15-35 \text { with TMD, using OCs at least for } 9 \text { months } \\
\text { Exclusion criteria: None }\end{array}$ \\
\hline Dao et al. & $\begin{array}{l}\text { Modulation of myofascial } \\
\text { pain by the reproductive hor- } \\
\text { mones: a preliminary report } \\
1998\end{array}$ & $\begin{array}{l}\text { Location: Canada } \\
\text { Age: } 18-41 \text { years } \\
\text { Sex: Females } \\
\text { Sample size: } 12 \\
\text { Study group: } 5 \text { females using oral contraceptives (OCs) } \\
\text { Control group: } 7 \text { females not using OCs } \\
\text { Inclusion criteria: } \\
\text { Regularly menstruating (24-35 day cycle) } \\
\text { Pain in the jaw, temples, face, or preauricular area of a least } 6 \text { months' duration, } \\
\text { with or without limited mouth opening } \\
\text { Axis I group I diagnosis according to RDC/TMD criteria } \\
\text { Exclusion criteria: } \\
\text { Clinical and/or radiographic signs or symptoms similar to the ones described for } \\
\text { the categories "disk displacements" or "arthralgia, osteoarthritis, osteoarthro- } \\
\text { sis" in the RDC. } \\
\text { Metabolic disease (e.g., diabetes, hyperthyroidism). Neurologic disorders (e.g., } \\
\text { dyskinesia, trigeminal neuralgia). Recent facial or cervical trauma. Migraine, } \\
\text { tension-type headache. } \\
\text { Chronic pelvic and abdominal pain. Neoplasia. History of psychiatric disorders or } \\
\text { current psychiatric treatment. Patients currently receiving medication or other } \\
\text { treatments that could not be stopped before and during the study. }\end{array}$ \\
\hline Hatch et al. & $\begin{array}{l}\text { Is use of exogenous estrogen } \\
\text { associated with temporo- } \\
\text { mandibular signs and } \\
\text { symptoms? } \\
2001\end{array}$ & $\begin{array}{l}\text { Location: USA } \\
\text { Age: } 37-82 \text { years } \\
\text { Sex: Females } \\
\text { Sample size: } 510 \\
\text { Study group: } 174 \text { women taking medications containing estrogens } \\
\text { Control group: } 336 \text { women not taking medications containing estrogens } \\
\text { Inclusion criteria: None } \\
\text { Exclusion criteria: Pregnancy, subjects whose ethnic group affiliation could not be } \\
\text { identified as Mexican American or European American according to a standard- } \\
\text { ized algorithm }\end{array}$ \\
\hline LeResche et al. & $\begin{array}{l}\text { Changes in temporomandib- } \\
\text { ular pain and other symp- } \\
\text { toms across the menstrual } \\
\text { cycle } \\
2003\end{array}$ & $\begin{array}{l}\text { Location: USA } \\
\text { Age: } 18-45 \text { years } \\
\text { Sex: Females and males } \\
\text { Sample size: } 126 \\
\text { Study groups: } \\
\text { Group 1: } 35 \text { females with TMD using OCs } \\
\text { Group 2: } 35 \text { females with TMD not using OCs } \\
\text { Group 3: } 21 \text { males with TMD } \\
\text { Control group: } 35 \text { females without TMD, severe headache, back pain or other } \\
\text { chronic pain problems who did not use OCs } \\
\text { Inclusion criteria: Criteria for all subjects: } 18-45 \text { years of age, generally healthy } \\
\text { and able to read and write in English, axis I both group I and III diagnosis accord- } \\
\text { ing to RDC/TMD criteria } \\
\text { Group 1: Women using oral contraceptives had to be using low dose combina- } \\
\text { tion (estrogen and progesterone) pills and had to have been on the pills for at } \\
\text { least 3 months } \\
\text { Group 2: Regular menstrual cycles (length of the cycle varied by no more than } \\
\pm 3 \text { days), not using oral contraceptives for at least } 3 \text { months } \\
\text { Group 3: Males } \\
\text { Exclusion criteria: } \\
\text { Group 1: Women using any other form of hormonal therapy were excluded from } \\
\text { the study }\end{array}$ \\
\hline
\end{tabular}


Tab. III. Cont.

\begin{tabular}{|c|c|c|}
\hline Authors & Title and year of publication & Material \\
\hline Landi et al. & $\begin{array}{l}17-\beta \text {-estradiol and pro- } \\
\text { gesterone serum levels in } \\
\text { temporomandibular disorder } \\
\text { patients } \\
2004\end{array}$ & $\begin{array}{l}\text { Location: Italy } \\
\text { Age: "young adults" } \\
\text { Sex: Females and males } \\
\text { Sample size: } 59 \\
\text { Study group: } 35 \text { patients with axis I group II and/or III diagnosis according to } \\
\text { RDC/TMD criteria } \\
\text { Control group: } 24 \text { age-matched healthy subjects of both sexes } \\
\text { Inclusion criteria: Axis I group II and/or III diagnosis according to RDC/TMD } \\
\text { criteria } \\
\text { Exclusion criteria: None }\end{array}$ \\
\hline LeResche et al. & $\begin{array}{l}\text { Musculoskeletal orofacial } \\
\text { pain and other signs and } \\
\text { symptoms of temporoman- } \\
\text { dibular disorders during preg- } \\
\text { nancy: a prospective study } \\
2005\end{array}$ & $\begin{array}{l}\text { Location: USA } \\
\text { Age: Study group: mean } 28.5 \text { years; Control group: mean } 28.4 \text { years } \\
\text { Sex: Females } \\
\text { Sample size: } 35 \\
\text { Study group: } 19 \text { pregnant females with myofascial pain: } \\
4 \text { with group I RDC/TMD diagnosis } \\
5 \text { with group I and II RDC/TMD diagnosis } \\
5 \text { with group I and IIIa/ IIIb RDC/TMD diagnosis } \\
2 \text { with group I, II, IIIa RDC/TMD diagnosis } \\
3 \text { females with myofascial pain that does not meet RDC/TMD criteria } \\
\text { Control group: } 16 \text { pregnant female, age-matched controls } \\
\text { Inclusion criteria: Pregnant females treated for TMD, with myofascial pain, who } \\
\text { are in the third trimester } \\
\text { Exclusion criteria: None }\end{array}$ \\
\hline Landi et al. & $\begin{array}{l}\text { Sexual hormone serum levels } \\
\text { and temporomandibular } \\
\text { disorders. } \\
\text { A preliminary study } \\
2005\end{array}$ & $\begin{array}{l}\text { Location: Italy } \\
\text { Age: } 21-29 \text { years } \\
\text { Sex: Females and males } \\
\text { Sample size: } 72 \\
\text { Study groups: } \\
\text { Group 1: } 20 \text { females with TMD } \\
\text { Group 2: } 20 \text { males with TMD } \\
\text { Control groups: } \\
\text { Group 3: } 16 \text { females without TMD } \\
\text { Group 4: } 16 \text { males without TMD } \\
\text { Inclusion criteria: Axis I group II and/or III diagnosis according to RDC/TMD } \\
\text { criteria } \\
\text { Exclusion criteria: None }\end{array}$ \\
\hline Sherman et al. & $\begin{array}{l}\text { Cyclic effects on experimen- } \\
\text { tal pain response in women } \\
\text { with temporomandibular } \\
\text { disorders } \\
2005\end{array}$ & $\begin{array}{l}\text { Location: USA } \\
\text { Age: } 18-45 \\
\text { Sex: Females } \\
\text { Sample size: } 94 \\
\text { Study group: Subjects were } 18 \text { normally cycling women with TMD who were not } \\
\text { using OCs and } 25 \text { women with TMD who used OCs. } \\
\text { Control group: Controls were } 25 \text { normally cycling women not using OCs and } 26 \\
\text { women who were using OCs. OCs used in both groups were required to be low } \\
\text { dose combination (estrogen plus progesterone) pills used in a cycle of } 21 \text { days of } \\
\text { active medication followed by } 7 \text { days without active medication. } \\
\text { Inclusion criteria: Subjects with TMD were required to have had pain for the last } \\
3 \text { months and to meet Research Diagnostic Criteria for Temporomandibular Disor- } \\
\text { ders (RDC/TMD) for both myofascial pain (i.e., Group la or Group Ib) and arthralgia } \\
\text { or arthritis (Group Illa or Illb). } \\
\text { Exclusion criteria: Participants were excluded if they reported average menstrual } \\
\text { pain in the last } 3 \text { months of intensity greater than or equal to } 4 \text { on a } 0 \text {-to-10 } \\
\text { scale, a history of hypertension, or coagulation problems, or if they were taking } \\
\text { any blood pressure-altering or opioidergic medications. Subjects were asked to } \\
\text { refrain from taking any analgesic medications on study visit days. }\end{array}$ \\
\hline $\begin{array}{l}\text { Nekora-Azak } \\
\text { et al. }\end{array}$ & $\begin{array}{l}\text { Estrogen replacement thera- } \\
\text { py among postmenopausal } \\
\text { women and its effects on } \\
\text { signs and symptoms of tem- } \\
\text { poromandibular disorders }\end{array}$ & $\begin{array}{l}\text { Location: Turkey } \\
\text { Age: } 42-72 \text { years } \\
\text { Sex: Females } \\
\text { Sample size: } 180 \\
\text { Study group: } 91 \text { females using hormone replacement therapy } \\
\text { Control group: } 89 \text { females not using hormone replacement therapy } \\
\text { Inclusion criteria: "Females not menstruating who reached menopause surgically } \\
\text { or naturally." } \\
\text { Exclusion criteria: "Recent facial or cervical trauma; history of general neurologi- } \\
\text { cal disorders; migraine or tension type headaches; major psychiatric disorders." }\end{array}$ \\
\hline
\end{tabular}


Tab. IV. Data extraction: results and conclusions

\begin{tabular}{|c|c|c|c|}
\hline Authors & $\begin{array}{l}\text { Title and year of } \\
\text { publication }\end{array}$ & Results & Authors' conclusions \\
\hline $\begin{array}{l}\text { LeResche } \\
\text { et al. }\end{array}$ & $\begin{array}{l}\text { Use of exogenous } \\
\text { hormones and the risk } \\
\text { of temporomandibular } \\
\text { disorder pain } \\
1997\end{array}$ & $\begin{array}{l}\text { Study I } \\
\text { "Over one-quarter of TMD cases ( } 28.5 \%) \text { were } \\
\text { users of estrogen replacements, as compared } \\
\text { with } 19.4 \% \text { of controls. The difference was } \\
\text { highly statistically significant." } \\
\text { Study II } \\
\text { "In analyses of oral contraceptives (OCs) use, } \\
27.4 \% \text { of the cases referred for TMD treatment, } \\
\text { compared with } 24.3 \% \text { of the controls were found } \\
\text { to be users of OCs. In this large sample of cases, } \\
\text { this difference is statistically significant." }\end{array}$ & $\begin{array}{l}\text { "The two studies presented here were } \\
\text { consistent in indicating an increased risk } \\
\text { of TMD pain among women using } \\
\text { various forms of exogenous hormones." }\end{array}$ \\
\hline Dao et al. & $\begin{array}{l}\text { Modulation of myo- } \\
\text { fascial pain by the re- } \\
\text { productive hormones: } \\
\text { a preliminary report } \\
1998\end{array}$ & $\begin{array}{l}\text { "Preliminary results showed that within the } \\
\text { menstrual cycle, variability of daily pain was } \\
\text { higher than the non-users group. In addition } \\
\text { to their low variation, pain levels of OCs users } \\
\text { remained positive across the hormonal cycle, } \\
\text { whereas in non-users, peaks of pain alternated } \\
\text { frequently with pain-free periods. These data } \\
\text { suggest that pain levels in OCs users may be } \\
\text { more constant than those of non-users." }\end{array}$ & $\begin{array}{l}\text { "This potential hormonal influence on } \\
\text { myofascial pain levels among OCs users } \\
\text { may represent one of the various adverse } \\
\text { effects induced by OCs at the trigeminal } \\
\text { area in sensitive subjects." } \\
\text { "The data from this study suggest that } \\
\text { MFP may be modulated by the reproduc- } \\
\text { tive hormones." }\end{array}$ \\
\hline $\begin{array}{l}\text { Hatch } \\
\text { et al. }\end{array}$ & $\begin{array}{l}\text { Is use of exogenous } \\
\text { estrogen associated } \\
\text { with temporoman- } \\
\text { dibular signs and } \\
\text { symptoms? } \\
2001\end{array}$ & $\begin{array}{l}\text { The muscle and joint signs and symptoms of } \\
\text { women taking estrogens were not significantly } \\
\text { different after the authors controlled for socio- } \\
\text { cultural, demographic and health care utilization } \\
\text { variables. Estrogen use also failed to distinguish } \\
\text { between women receiving relatively high and } \\
\text { low scores on the CMl. }\end{array}$ & $\begin{array}{l}\text { Estrogen replacement therapy does not } \\
\text { place women at an increased risk of devel- } \\
\text { oping TMD. }\end{array}$ \\
\hline $\begin{array}{l}\text { LeResche } \\
\text { et al. }\end{array}$ & $\begin{array}{l}\text { Changes in tempo- } \\
\text { romandibular pain } \\
\text { and other symptoms } \\
\text { across the menstrual } \\
\text { cycle } \\
2003\end{array}$ & $\begin{array}{l}\text { "There were no statistically significant differ- } \\
\text { ences among the groups in characteristic pain } \\
\text { intensity, pain interference or Graded Chronic } \\
\text { Pain. } \\
\text { In both groups, TMD pain levels rose toward the } \\
\text { end of the cycle and peaked during menstrua- } \\
\text { tion. } \\
\text { There was no statistically significant difference } \\
\text { over time periods for men. } \\
\text { For average pain, the patterns across the cycle } \\
\text { were similar to those for the worst pain." }\end{array}$ & $\begin{array}{l}\text { "TMD pain in women is the highest of } \\
\text { lowest estrogen but rapid estrogen change } \\
\text { may also be associated with increased } \\
\text { pain." }\end{array}$ \\
\hline $\begin{array}{l}\text { Landi } \\
\text { et al. }\end{array}$ & $\begin{array}{l}\text { 17- } \beta \text {-estradiol and pro- } \\
\text { gesterone serum levels } \\
\text { in temporomandibular } \\
\text { disorder patients } \\
2004\end{array}$ & $\begin{array}{l}\text { "Significant differences between patients af- } \\
\text { fected by TMJ disorders and healthy controls } \\
\text { were found for serum concentration of 17-beta- } \\
\text { estradiol, both in males and in the luteal phase } \\
\text { of the menstrual cycle in females. No difference } \\
\text { was found for progesterone serum levels in dif- } \\
\text { ferent experimental samples." }\end{array}$ & $\begin{array}{l}\text { "The results of this study suggest that } \\
\text { high serum estrogens levels might be } \\
\text { implicated in the physiopathology of } \\
\text { temporomandibular joint disorders, since } \\
\text { subjects with these pathologies showed } \\
\text { significantly higher serum levels with } \\
\text { respect to a group of healthy controls." }\end{array}$ \\
\hline $\begin{array}{l}\text { LeResche } \\
\text { et al. }\end{array}$ & $\begin{array}{l}\text { Musculoskeletal oro- } \\
\text { facial pain and other } \\
\text { signs and symptoms } \\
\text { of temporomandibu- } \\
\text { lar disorders during } \\
\text { pregnancy: a prospec- } \\
\text { tive study } \\
2005\end{array}$ & $\begin{array}{l}\text { "At baseline (third month of pregnancy), } 16 \text { of } \\
\text { the } 19 \text { patients with musculoskeletal orofacial } \\
\text { pain met criteria for an RDC/TMD diagnosis. } \\
\text { Reported musculoskeletal orofacial pain dimin- } \\
\text { ished significantly during the second or third } \\
\text { trimester of pregnancy and increased again } \\
\text { postpartum." }\end{array}$ & $\begin{array}{l}\text { "Musculoskeletal orofacial pain and } \\
\text { related symptoms appear to improve over } \\
\text { the course of pregnancy. This improve- } \\
\text { ment occurs in the presence of increased } \\
\text { joint laxity and is not paralleled by } \\
\text { improvements in psychological distress. } \\
\text { Thus, it was concluded that the improve- } \\
\text { ment in pain is most likely associated with } \\
\text { the dramatic hormonal changes occurring } \\
\text { during pregnancy." }\end{array}$ \\
\hline $\begin{array}{l}\text { Landi } \\
\text { et al. }\end{array}$ & $\begin{array}{l}\text { Sexual hormone } \\
\text { serum levels and } \\
\text { temporomandibular } \\
\text { disorders. } \\
\text { A preliminary study } \\
2005\end{array}$ & $\begin{array}{l}\text { "Our results showed significantly higher serum } \\
\text { levels in patients affected by TMD than in } \\
\text { healthy controls, both in males and in the luteal } \\
\text { phase of the menstrual cycle in females, while } \\
\text { no difference was found for progesterone serum } \\
\text { levels." }\end{array}$ & $\begin{array}{l}\text { "Considering the multifactorial etiology of } \\
\text { TMD and the hypothesis that some joint } \\
\text { tissues (e.g., bone, cartilage, collagen, } \\
\text { proteins) could be a target for sexual } \\
\text { hormones, these data suggest that high } \\
\text { serum estrogen levels might be implicated } \\
\text { in the physiopathology of TMD." }\end{array}$ \\
\hline
\end{tabular}


Tab. IV. Cont.

\begin{tabular}{|c|c|c|c|}
\hline $\begin{array}{l}\text { Sherman } \\
\text { et al. }\end{array}$ & $\begin{array}{l}\text { Cyclic effects on } \\
\text { experimental pain re- } \\
\text { sponse in women with } \\
\text { temporomandibular } \\
\text { disorders } \\
2005\end{array}$ & $\begin{array}{l}\text { "Significant phase-related differences were seen } \\
\text { for palpation intensity measures ( } P \text { values .05). } \\
\text { Normally cycling women with TMD showed } \\
\text { higher palpation pain intensity at menses and } \\
\text { midluteal phases, while women with TMD taking } \\
\text { OCs showed stable palpation pain intensity rat- } \\
\text { ings at menses, ovulatory, and midluteal phases, } \\
\text { with increased intensity at the late luteal phase. } \\
\text { TMD subjects had greater palpation pain and } \\
\text { ischemic pain intensity and lower pressure pain } \\
\text { thresholds compared to controls." }\end{array}$ & $\begin{array}{l}\text { "Phase-related differences in experimental } \\
\text { pain response were not strong and were } \\
\text { more often found for experimental stimuli } \\
\text { with greater clinical relevance (i.e., palpa- } \\
\text { tion pain) compared with an ischemic pain } \\
\text { task." }\end{array}$ \\
\hline $\begin{array}{l}\text { Nekora- } \\
\text { Azak } \\
\text { et al. }\end{array}$ & $\begin{array}{l}\text { Estrogen replacement } \\
\text { therapy among post- } \\
\text { menopausal women } \\
\text { and its effects on } \\
\text { signs and symptoms } \\
\text { of temporomandibular } \\
\text { disorders }\end{array}$ & $\begin{array}{l}\text { "There was no significant difference found in the } \\
\text { signs and symptoms of TMD between post- } \\
\text { menopausal women using hormone therapy and } \\
\text { those not using postmenopausal hormones." }\end{array}$ & $\begin{array}{l}\text { "There was no association between the } \\
\text { use of postmenopausal hormones and the } \\
\text { signs and symptoms of TMD in this study." }\end{array}$ \\
\hline & 2008 & & \\
\hline
\end{tabular}

Tab. V. Scoring questions and scores

\begin{tabular}{|c|c|c|}
\hline \multicolumn{2}{|c|}{ Questions } & \multirow{2}{*}{$\begin{array}{l}\text { Scoring } \\
0-9-0 \text { pts } \\
10-99-1 \text { pt } \\
>100-2 \text { pts }\end{array}$} \\
\hline Q1 & $\begin{array}{l}\text { Sample } \\
\text { size }\end{array}$ & \\
\hline Q2 & $\begin{array}{l}\text { Control } \\
\text { group }\end{array}$ & $\begin{array}{l}\text { none }-0 \text { pts } \\
\text { present }-2 \text { pts }\end{array}$ \\
\hline Q3 & $\begin{array}{l}\text { Inclusion } \\
\text { criteria }\end{array}$ & $\begin{array}{l}\text { none }-0 \text { pts } \\
\text { present, not restricted to one form of } \\
\text { TMD }-1 \text { pt } \\
\text { restricted to one form of TMD }-2 \text { pts }\end{array}$ \\
\hline Q4 & $\begin{array}{l}\text { Exclusion } \\
\text { criteria }\end{array}$ & $\begin{array}{l}\text { none }-0 \text { pts } \\
\text { concomitant pain disorders OR other } \\
\text { medications use }-1 \text { pt } \\
\text { concomitant pain disorders AND other } \\
\text { medications use }-2 \text { pts }\end{array}$ \\
\hline Q5 & $\begin{array}{l}\text { Use of } \\
\text { standard- } \\
\text { ized ex- } \\
\text { amination } \\
\text { protocol }\end{array}$ & $\begin{array}{l}\text { none }-0 \text { pts } \\
\text { RDC/TMD }-2 \text { pts } \\
\text { other protocols }-1 \text { pt }\end{array}$ \\
\hline Q6 & $\begin{array}{l}\text { Estrogen } \\
\text { level as- } \\
\text { sessment }\end{array}$ & $\begin{array}{l}\text { none }-0 \text { pt } \\
\text { assessment based on the phase of } \\
\text { the menstrual cycle }-1 \text { pt } \\
\text { measured in blood or saliva samples } \\
-2 \text { pts }\end{array}$ \\
\hline Q7 & $\begin{array}{l}\text { Conflict of } \\
\text { interest }\end{array}$ & $\begin{array}{l}\text { present }-0 \text { pts } \\
\text { no data }-1 \text { pt } \\
\text { none }-2 \text { pts }\end{array}$ \\
\hline
\end{tabular}

with the morphology of the face and jaw dimensions [40]. There is still insufficient evidence to support the hypothesis that endogenous and exogenous estrogen and estrogen receptor polymorphisms affect joint health in humans [41].

The decrease in TMD pain in pregnancy reported by LeResche et al. is thought to be associated with an increase in joint laxity in this period, but it is also highly probable that pain regulatory mechanisms may also be implicated, as a similar decrease in pain is seen in pregnant migraine patients [30]. Two reviewed papers [27, 28] found a relationship between a low estrogen level and an increase in TMD pain, which can be partly confirmed by the results of animal studies. As mentioned before, estrogen's effect on pain signaling is very complex because estrogen can affect different pain mechanisms [21, 42]. Results suggesting that low estrogen increases pain can be confirmed by comparison with the results of animal studies on the effect of estrogen on physiological and acute inflammatory pain.

Estrogen acts as an anti-nociceptive, causing changes in the levels of neurotransmitters in DRG in physiologic pain - an increase in calcitonin gene-related peptide (CGRP) and a decrease in substance $P$, and, a decrease in the expression of $P 2 X 3$ receptors in DRG and the trigeminal ganglion. Expression of anti-nociceptive neurotransmitters such as neuropeptide $Y$, galanin and ghrelin in the trigeminal ganglion changes in the course of the menstrual cycle increasing with estrogen levels. A correlation between high estrogen and decreased physiologic pain is seen. The estrogen-dependent decrease in pain was also observed in humans during menstruation and hormonal therapies [43-47]. On the other hand, estrogen can act as a pro-nociceptive in chronic inflammatory pain. In two reviewed studies $[26,30]$, patients with a suspected high level of estrogen suffered from myofascial pain, where there is no inflammatory component, so we can suspect that the studies revealed the effect of estrogen on physiological pain processing. It is worth noting that estrogen acting through its receptors, increases activity of $N$-methyl- $D$ aspartic acid (NMDA) receptors in DRG, causing release of pro-nociceptive neuropeptides such as substance $P$, CGRP and brain-derived neurotrophic factor (BDNF). These mechanisms are responsible for sex differences in temporal summation and development of central sen- 
Tab. VI. Scoring

\begin{tabular}{|c|c|c|c|c|c|c|c|c|c|}
\hline \multirow[t]{2}{*}{ Authors } & \multirow[t]{2}{*}{ Title } & \multicolumn{7}{|c|}{ Scoring } & \multirow[t]{2}{*}{ Total } \\
\hline & & Q1 & Q2 & Q3 & Q4 & Q5 & Q6 & Q7 & \\
\hline LeResche et al. & $\begin{array}{l}\text { Use of exogenous hormones and risk of temporoman- } \\
\text { dibular disorder pain, } 1997\end{array}$ & 2 & 2 & 0 & 0 & 1 & 0 & 2 & 7 \\
\hline Dao et al. & $\begin{array}{l}\text { Modulation of myofascial pain by the reproductive } \\
\text { hormones: a preliminary report, } 1998\end{array}$ & 1 & 2 & 2 & 2 & 2 & 1 & 1 & 11 \\
\hline Hatch et al. & $\begin{array}{l}\text { Is use of exogenous estrogen associated with temporo- } \\
\text { mandibular signs and symptoms?, } 2001\end{array}$ & 2 & 2 & 0 & 1 & 1 & 0 & 2 & 8 \\
\hline LeResche et al. & $\begin{array}{l}\text { Changes in temporomandibular pain and other symp- } \\
\text { toms across the menstrual cycle, } 2003\end{array}$ & 2 & 2 & 2 & 1 & 2 & 1 & 2 & 12 \\
\hline Landi et al. & $\begin{array}{l}\text { 17- -estradiol and progesterone serum levels in tempo- } \\
\text { romandibular disorder patients, } 2004\end{array}$ & 1 & 2 & 2 & 0 & 2 & 2 & 1 & 10 \\
\hline LeResche et al. & $\begin{array}{l}\text { Musculoskeletal orofacial pain and other signs and } \\
\text { symptoms of temporomandibular disorders during } \\
\text { pregnancy: a prospective study, } 2005\end{array}$ & 1 & 2 & 1 & 0 & 2 & 0 & 2 & 8 \\
\hline Landi et al. & $\begin{array}{l}\text { Sexual hormone serum levels and temporomandibular } \\
\text { disorders. A preliminary study, } 2005\end{array}$ & 1 & 2 & 2 & 0 & 2 & 2 & 2 & 11 \\
\hline Sherman et al. & $\begin{array}{l}\text { Cyclic effects on experimental pain response in women } \\
\text { with temporomandibular disorders, } 2005\end{array}$ & 1 & 2 & 2 & 2 & 2 & 1 & 2 & 12 \\
\hline Nekora-Azak et al. & $\begin{array}{l}\text { Estrogen replacement therapy among postmenopausal } \\
\text { women and its effects on signs and symptoms of tem- } \\
\text { poromandibular disorders, } 2008\end{array}$ & 2 & 2 & 1 & 1 & 1 & 0 & 1 & 8 \\
\hline
\end{tabular}

sitization [48]. These mechanisms could be associated with chronic forms of TMD pain. In contrast to studies by Landi et al., Dao et al. showed that use of exogenous estrogen does not influence the mean pain intensity in myofascial TMD. However, the levels of pain in patients using oral contraceptives (OCs) are more constant than in non-users. While LeResche et al. did not find differences in the variability of pain between women taking oral contraceptives and normally cycling women [24]. They suggest that any discrepancies may be due to the fact that their subjects suffered from joint pain as well as myofascial pain. Alternately, a larger sample of the study could explain discrepancies. LeResche et al. further suggest that not only estrogen levels, but also rapid changes of hormone levels put women at a higher risk of experiencing pain. This opinion is also shared by other authors. The effect of estrogen depends on its level, time of exposition and rapid or cyclic changes [22, 49].

It is worth noting that other sex hormones can influence TMD pathophysiology and interfere with estrogen. The influence of estrogen on TMD seems to be multifaceted and it may differently affect certain aspects of TMD. When taking into account that estrogen may be associated only with certain subgroups of TMD or differently affect them, mixed groups of TMD patients may be inappropriate for TMD pain studies and cause difficulties in interpretation of the outcomes. For instance, a combination of group I and II or group II and III (according to RDC/TMD) does not enable the evaluation of a clear association between estrogen and pain regulatory mechanisms. While most of the studies were based on animal models, only a few were performed on human populations. The latest research of Nekora-Azak et al. was published in 2008 , which signalizes stagnation in this area of knowledge [31].

\section{Conclusions}

Results of reviewed studies were divergent and sometimes contradictory. Thus, we suggest consideration of the dual action of estrogen when planning future studies on its association with TMD.

In our opinion, when planning future studies on influence of estrogen on TMD, it is essential to use a standardized examination method of TMD to enable comparison of outcomes between the studies (e.g. RDC/TMD). Estrogen level assessment should always be provided in order to improve data reliability. When evaluating hormonal therapies, researchers should always indicate the type of therapy used. When creating study groups for explanatory studies, patients with mixed TMD diagnoses should not be included because estrogen has different effects on various components of TMD.

\section{Disclosure}

Authors report no conflict of interest.

\section{References}

1. Romero-Reyes M, Uyanik JM. Orofacial pain management: current perspectives. J Pain Res 2014; 7: 99-115.

2. Michelotti A, Liguori R, Toriello M, et al. Catechol-O-methyltransferase (COMT) gene polymorphisms as risk factor in temporomandibular disorders patients from Southern Italy. Clin J Pain 2014; 30: 129-133. 
3. Smith SB, Mir E, Bair E, et al. Genetic variants associated with development of TMD and its intermediate phenotypes: the genetic architecture of TMD in the OPPERA prospective cohort study. J Pain Off J Am Pain Soc 2013; 14: T91-101.e1-3.

4. Melis M, Giosia MD. The role of genetic factors in the etiology of temporomandibular disorders: a review. Cranio J Craniomandib Pract 2014; 2151090314 Y0000000027.

5. LeResche L. Epidemiology of temporomandibular disorders: implications for the investigation of etiologic factors. Crit Rev Oral Biol Med Off Publ Am Assoc Oral Biol 1997; 8: 291-305.

6. Manfredini D, Guarda-Nardini L, Winocur E, et al. Research diagnostic criteria for temporomandibular disorders: a systematic review of axis I epidemiologic findings. Oral Surg Oral Med Oral Pathol Oral Radiol Endod 2011; 112: 453-462.

7. Funakoshi T, Yanai A, Shinoda K, et al. G protein-coupled receptor 30 is an estrogen receptor in the plasma membrane. Biochem Biophys Res Commun 2006; 346: 904-910.

8. Puri J, Hutchins B, Bellinger LL, et al. Estrogen and inflammation modulate estrogen receptor alpha expression in specific tissues of the temporomandibular joint. Reprod Biol Endocrinol 2009; 7: 155

9. Cheng P, Ma X, Li S. Histologic study of the temporomandibular joints after ovariectomy in rats. Zhonghua Kou Qiang Yi Xue Za Zhi Zhonghua Kouqiang Yixue Zazhi Chin J Stomatol 2000; 35: 458-461.

10. Fujita T, Kawata T, Tokimasa C, et al. Influences of ovariectomy and orchiectomy on the remodeling of mandibular condyle in mice. J Craniofac Genet Dev Biol 1998; 18: 164-170.

11. Fujita T, Kawata T, Tokimasa C, et al. Breadth of the mandibular condyle affected by disturbances of the sex hormones in ovariectomized and orchiectomized mice. Clin Orthod Res 2001; 4: 172-176.

12. Okuda T, Yasuoka T, Nakashima M, et al. The effect of ovariectomy on the temporomandibular joints of growing rats. J Oral Maxillofac Surg 1996; 54: 1201-1210.

13. Yamashiro T, Takano-Yamamoto T. Differential responses of mandibular condyle and femur to oestrogen deficiency in young rats. Arch Oral Biol 1998; 43: 191-195.

14. Yasuoka T, Nakashima M, Okuda T, et al. Effect of estrogen replacement on temporomandibular joint remodeling in ovariectomized rats. J Oral Maxillofac Surg 2000; 58: 189-196.

15. Wang J, Chao Y, Wan Q, et al. The possible role of estrogen in the incidence of temporomandibular disorders. Med Hypotheses 2008; 71 564-567.

16. Ezio Bettini GP. Estrogen receptor in rat brain: presence in the hippocampal formation. Neuroendocrinology 1992; 56: 502-508.

17. Papka RE, Srinivasan B, Miller KE, et al. Localization of estrogen receptor protein and estrogen receptor messenger RNA in peripheral autonomic and sensory neurons. Neuroscience 1997; 79: 1153-1163.

18. Kou X-X, Wu Y-W, Ding Y, et al. 17 -estradiol aggravates temporomandibular joint inflammation through the NF- B pathway in ovariectomized rats. Arthritis Rheum 2011; 63: 1888-1897.

19. Liverman C, Brown J, Sandhir R, et al. Oestrogen increases nociception through ERK activation in the trigeminal ganglion: evidence for a peripheral mechanism of allodynia. Cephalalgia Int J Headache 2009; 29: 520-531.

20. Lu Y, Li Z, Li H, et al. A comparative study of the effect of $17 \beta$-estradiol and estriol on peripheral pain behavior in rats. Steroids 2012; 77: 241-249.

21. Torres-Chávez KE, Sanfins JM, Clemente-Napimoga JT, et al. Effect of gonadal steroid hormones on formalin-induced temporomandibular joint inflammation. Eur J Pain 2012; 16: 204-216.

22. Puri J, Bellinger LL, Kramer PR. Estrogen in cycling rats alters gene expression in the temporomandibular joint, trigeminal ganglia and trigeminal subnucleus caudalis/upper cervical cord junction. J Cell Physiol 2011; 226: 3169-3180

23. Meloto CB, Serrano PO, Ribeiro-DaSilva MC et al. Genomics and the new perspectives for temporomandibular disorders. Arch Oral Bio 2011; 56: 1181-1191.

24. LeResche L, Mancl L, Sherman JJ, et al. Changes in temporomandibula pain and other symptoms across the menstrual cycle. Pain 2003; 106 253-261.

25. Sherman JJ, LeResche L, Manci LA, et al. Cyclic effects on experimental pain response in women with temporomandibular disorders. J Orofac Pain 2005; 19: 133-143.
26. Dao TTT, Knight K, Ton-That V. Modulation of myofascial pain by the reproductive hormones: a preliminary report. J Prosthet Dent 1998; 79: 663-670.

27. Landi N, Manfredini D, Lombardi I, et al. 17-beta-estradiol and progesterone serum levels in temporomandibular disorder patients. Minerva Stomatol 2004: 53: 651-660.

28. Landi N, Lombardi I, Manfredini D, et al. Sexual hormone serum levels and temporomandibular disorders. A preliminary study. Gynecol Endocrinol 2005; 20: 99-103.

29. Hatch JP, Rugh JD, Sakai S, et al. Is use of exogenous estrogen associated with temporomandibular signs and symptoms? J Am Dent Assoc 2001; 132: 319-326.

30. LeResche L, Sherman JJ, Huggins K, et al. Musculoskeletal orofacial pain and other signs and symptoms of temporomandibular disorders during pregnancy: a prospective study. J Orofac Pain 2005; 19: 193-201.

31. Nekora-Azak A, Evlioglu G, Ceyhan A, et al. Estrogen replacement therapy among post-menopausal women and its effects on signs and symptoms of temporomandibular disorders. Cranio 2008; 26: 211-215.

32. LeResche L, Saunders K, Von Korff MR, et al. Use of exogenous hormones and risk of temporomandibular disorder pain. Pain 1997; 69: 153-160.

33. Warren MP, Fried JL. Temporomandibular disorders and hormones in women. Cells Tissues Organs 2001; 169: 187-192

34. Martin MD, Wilson KJ, Ross BK, et al. Intubation risk factors for temporomandibular joint/facial pain. Anesth Prog 2007; 54: 109-114

35. Kapila S, Wang W, Uston K. MMP Induction by Relaxin Causes Cartilage Matrix Degradation in Target Synovial Joints: Receptor Profiles Correlate with Matrix Turnover. Ann N Y Acad Sci 2009; 1160: 322-328.

36. Cheng P, Ma X, Xue Y, et al. Effects of estradiol on proliferation and metabolism of rabbit mandibular condylar cartilage cells in vitro. Chin Med I (Engl) 2003; 116: 1413-1417.

37. Kapila S, Xie Y. Targeted induction of collagenase and stromelysin by relaxin in unprimed and beta-estradiol-primed diarthrodial joint fibrocartilaginous cells but not in synoviocytes. Lab Investig J Tech Methods Pathol 1998; 78: 925-938.

38. Corvol M, Blanchard O, Tsagris L. Bone and cartilage responsiveness to sex steroid hormones. J Steroid Biochem Mol Biol 1992; 43: 415-418.

39. Ames MS, Hong S, Lee HR, et al. Estrogen Deficiency Increases Variability of Tissue Mineral Density of Alveolar Bone Surrounding Teeth. Arch Oral Biol 2010; 55: 599-605.

40. Lee GS, Kim HJ, Jung YW, et al. Estrogen receptor alpha pathway is involved in the regulation of Calbindin-D9k in the uterus of immature rats. Toxicol Sci 2005; 84: 270-277.

41. Tanamas SK, Wijethilake P, Wluka AE, et al. Sex hormones and structural changes in osteoarthritis: a systematic review. Maturitas 2011; 69: 141-156.

42. Zhang Y, Lü N, Zhao ZQ, et al. Involvement of estrogen in rapid pain modulation in the rat spinal cord. Neurochem Res 2012; 37: 2697-2705.

43. Drobek W, Schoenaers J, De Laat A. Hormone-dependent fluctuations of pressure pain threshold and tactile threshold of the temporalis and masseter muscle. J Oral Rehabil 2002; 29: 1042-1051.

44. Rezaii T, Ernberg M. Influence of oral contraceptives on endogenous pain control in healthy women. Exp Brain Res 2010; 203: 329-338.

45. Stening K, Eriksson O, Wahren L, et al. Pain sensations to the cold pressor test in normally menstruating women: comparison with men and relation to menstrual phase and serum sex steroid levels. Am J Physiol Regul Integr Comp Physiol 2007; 293: R1711-1716.

46. Stening KD, Berg G, Hammar M, et al. Influence of estrogen levels on thermal perception, pain thresholds, and pain tolerance: studies on women undergoing in vitro fertilization. J Pain 2012; 13: 459-466.

47. Teepker M, Peters M, Kundermann B, et al. The effects of oral contraceptives on detection and pain thresholds as well as headache intensity during menstrual cycle in migraine. Headache 2011; 51: 92-104.

48. McRoberts JA, Coutinho SV, Marvizón JCG, et al. Role of peripheral $\mathrm{N}$-methyl-D-aspartate (NMDA) receptors in visceral nociception in rats. Gastroenterology 2001; 120: 1737-1748.

49. Flake NM, Bonebreak DB, Gold MS. Estrogen and inflammation increase the excitability of rat temporomandibular joint afferent neurons. J Neu rophysiol 2005; 93: 1585-1597. 